\title{
Steam Reforming of Glycerol for Hydrogen Production over $\mathrm{Ni} / \mathrm{SiO}_{2}$ Catalyst
}

\section{G. Sadanandam, ${ }^{1}$ N. Sreelatha, ${ }^{1}$ M. V. Phanikrishna Sharma, ${ }^{2}$ S. Kishta Reddy, ${ }^{1}$ B. Srinivas, ${ }^{1}$ K. Venkateswarlu, ${ }^{3}$ T. Krishnudu, ${ }^{3}$ M. Subrahmanyam, ${ }^{1}$ and V. Durga Kumari ${ }^{1}$}

\author{
${ }^{1}$ Inorganic and Physical Chemistry Division, Indian Institute of Chemical Technology, Hyderabad 500 607, India \\ ${ }^{2}$ Department of Chemical Engineering, Hampton University, Hampton, VA 23668, USA \\ ${ }^{3}$ Coal and Gas Technology Division, Indian Institute of Chemical Technology, Hyderabad 500 607, India
}

Correspondence should be addressed to V. Durga Kumari, durgakumari@iict.res.in

Received 5 October 2012; Accepted 24 October 2012

Academic Editors: T. García, L. Jiang, and M. Kostoglou

Copyright (c) 2012 G. Sadanandam et al. This is an open access article distributed under the Creative Commons Attribution License, which permits unrestricted use, distribution, and reproduction in any medium, provided the original work is properly cited.

\begin{abstract}
The performance of $\mathrm{Ni} / \mathrm{SiO}_{2}$ catalyst for glycerol reforming has been investigated in fixed-bed reactor using careful tailoring of the operational conditions. In this paper, a commercial Engelhard catalyst has been sized and compared to gas product distribution versus catalyst size, water-to-carbon ratio, and stability of the catalyst system. $\mathrm{Ni} / \mathrm{SiO}_{2}$ catalysts of three sizes $(2 \times 2,2 \times 4$, and $3 \times 5 \mathrm{~mm}$ ) are evaluated using glycerol: water mixture at $600^{\circ} \mathrm{C}$ to produce $2 \mathrm{~L} \mathrm{H}_{2} \mathrm{~g}^{-1} \mathrm{cat} \mathrm{h}^{-1}$. The results indicate that $3 \times 5 \mathrm{~mm}$ size pellet is showing minimum coking and maintaining same level of conversion even after several hours of reforming activity. Whereas studies on $2 \times 2$ and $2 \times 4 \mathrm{~mm}$ pellets indicate that carbon formation is affecting the reforming activity. Under accelerated aging

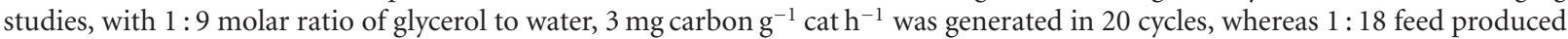
only $1.5 \mathrm{mg}$ carbon $\mathrm{g}^{-1} \mathrm{cat} \mathrm{h}^{-1}$ during the same cycles of operation. The catalysts were characterized before and after evaluation by X-ray diffraction (XRD), BET surface area, scanning electron microscopy (SEM) with energy dispersive X-ray spectroscopy (EDAX), CHNS analysis, transmission electron microscopy (TEM), and X-ray photo electron spectroscopy (XPS).
\end{abstract}

\section{Introduction}

The search for alternative energy sources is becoming an important aspect in the present scenario due to diminishing petroleum reserves and increased environmental pollution. Hydrogen production from biomass has great interest because of the potential application in fuel cells. Significant amount of glycerol is produced as a by-product in biodiesel production by transesterification of vegetable oils, which are available at low cost in large quantity from renewable raw materials. With increased production of biodiesel, an excess amount of glycerol $\left(\mathrm{C}_{3} \mathrm{H}_{8} \mathrm{O}_{3}\right)$ is expected in the world market [1]. At present, glycerol is used in many applications including personal care, food, oral care, tobacco, polymer, and pharmaceutical applications. Besides converting glycerol into value-added chemicals [2-4], hydrogen production through reforming is alternative route [5-12]. Aqueous phase reforming of oxygenated hydrocarbons is extensively studied by the Luo et al. and Shabaker et al. [9, 13], and glycerol steam reforming is studied by Czenik et al. [14], Pompeo et al. [10], and Adhikari et al. [6, 15] over nickelbased catalysts and noble metal catalysts on different supports [16-19]. Chiodo et al. reported carbon formation of 2-6 $\mathrm{mg}$ carbon $\mathrm{g}^{-1} \mathrm{cath}^{-1}$ by steam reforming of glycerol by $\mathrm{Ni}$ over $\mathrm{MgO}, \mathrm{CeO}_{2}, \mathrm{Al}_{2} \mathrm{O}_{3}$, and $\mathrm{Ru} / \mathrm{Al}_{2} \mathrm{O}_{3}$ catalysts for $20 \mathrm{~h}$ [20]. Adhikari et al. have reported $20-40 \mathrm{mg}$ carbon/100 mg catalyst over $\mathrm{Ni}$ supported $\mathrm{CeO}_{2}, \mathrm{MgO}$, and $\mathrm{TiO}_{2}$ for $2 \mathrm{~h}$ duration [21]. The thermodynamic analysis reported by Adhikari et al. suggests the best conditions for hydrogen production at temperatures higher than $900 \mathrm{~K}$ under atmospheric pressure with 1:9 molar ratio of glycerol to water $[6,22]$. Performance of metal-supported catalysts have been evaluated in terms of activity and hydrogen productivity, but no clear evidence has been reported to establish the most suitable catalyst system for glycerol steam reforming. 
TABle 1: Physical characteristics of $\mathrm{Ni} / \mathrm{SiO}_{2}$ catalysts.

\begin{tabular}{|c|c|c|c|c|c|c|}
\hline \multirow{2}{*}{$\begin{array}{l}\text { Catalyst - } \\
\text { (size-mm) }\end{array}$} & \multirow{2}{*}{$\begin{array}{c}\text { No. of } \\
\text { hours/cycles }\end{array}$} & \multirow{2}{*}{$\begin{array}{l}\text { Ni crystallite size } \\
(\mathrm{nm}) \text { form XRD }\end{array}$} & \multicolumn{2}{|c|}{ Surface composition from EDAX } & \multirow{2}{*}{$\begin{array}{c}\text { Carbon (\%) } \\
\text { from CHNS } \\
\text { analysis }\end{array}$} & \multirow{2}{*}{$\begin{array}{c}\text { BET surface area } \\
\left(\mathrm{m}^{2} / \mathrm{g}\right)\end{array}$} \\
\hline & & & $\mathrm{Ni} \%$ & $\mathrm{C} \%$ & & \\
\hline NS - $(2 \times 2)$ & $\cdots$ & 5.0 & 57 & $\cdots$ & $\cdots$ & 260 \\
\hline NS1 - $(2 \times 2)$ & $68 \mathrm{~h}$ & 5.7 & 6.3 & 77 & 60 & 107 \\
\hline NS2 - $(2 \times 4)$ & $20 \mathrm{~h}$ & 6.8 & 40 & 25 & 25 & 150 \\
\hline NS3 - $(3 \times 5)$ & $100 \mathrm{~h}$ & 7.8 & 25 & 20 & 20 & 125 \\
\hline NS4 - $(3 \times 5)$ & $20 \mathrm{cy}$ & 12.5 & 28 & 35 & 30 & 145 \\
\hline NS5 $-(3 \times 5)$ & $20 \mathrm{cy}^{*}$ & 20.1 & 37.6 & 12 & 15 & $\ldots$ \\
\hline
\end{tabular}

Number of hours of the run $=h$; number of cycles operated $=$ cy.

GWMRs: $1: 9 *$ GWMRs: $1: 18$.

$\mathrm{NS}(2 \times 2)=\mathrm{Ni} / \mathrm{SiO}_{2}$ (fresh catalyst); NS1, NS2, NS3, NS4, and NS5 $=\mathrm{Ni} / \mathrm{SiO}_{2}$ (used catalysts).

The steam reforming reaction of glycerol proceeds according to the following equations.

First, the decomposition of glycerol into syn-gas:

$$
\mathrm{C}_{3} \mathrm{H}_{8} \mathrm{O}_{3} \longrightarrow 3 \mathrm{CO}+4 \mathrm{H}_{2}
$$

followed by the water-gas-shift reaction:

$$
\mathrm{CO}+\mathrm{H}_{2} \mathrm{O} \underset{\text { High } \mathrm{T}: \text { rev:WGS }}{\stackrel{\text { Low } \mathrm{T}: \text { WGS }}{\rightleftharpoons}} \mathrm{CO}_{2}+\mathrm{H}_{2}
$$

The stoichiometric glycerol steam reforming process is represented as:

$$
\mathrm{C}_{3} \mathrm{H}_{8} \mathrm{O}_{3}+3 \mathrm{H}_{2} \mathrm{O} \longrightarrow 3 \mathrm{CO}_{2}+7 \mathrm{H}_{2}
$$

Steam reforming of glycerol involves complex reactions that results in several intermediates affecting the selectivity of the hydrogen. Furthermore, hydrogen production and carbon deposition strongly depend on different operating conditions, such as glycerol-to-water molar ratio, temperature, contact time, and pressure. The deactivation of catalysts can be minimized by operating at lower glycerol-to-water molar ratio (GWMRs). So far, all the published papers do not report the use of $\mathrm{Ni} / \mathrm{SiO}_{2}$ catalyst for glycerol steam reforming except Pompeo et al. [10] with only $5 \mathrm{wt} \% \mathrm{Ni}$ on $\mathrm{SiO}_{2}$ support. The results do not clear the evidence to establish the most suitable catalyst system for glycerol steam reforming:

$$
\begin{gathered}
\mathrm{CH}^{*} \longrightarrow \mathrm{C} \\
\mathrm{C}^{*}+\mathrm{OH}^{*} \longrightarrow \mathrm{CO}(\mathrm{g})+\frac{1}{2} \mathrm{H}_{2}(\mathrm{~g})
\end{gathered}
$$

In the present study, carbon formation during glycerol reforming process was investigated. In our experiments, coke formation was found to be the main reason for the deactivation of $\mathrm{Ni} / \mathrm{SiO}_{2}$ catalysts. Small size of the catalyst and higher GWMRs promote carbon deposition. The use of small catalyst particles reduces the internal mass-transfer limitation even though they are limited by relatively high pressure drops, mal distribution of flows, and hot spots that alter selectivity of the process. The selections of the right size of the catalyst overcome these drawbacks. We report results of experimental studies on the rates of $\mathrm{H}_{2}, \mathrm{CO}_{2}, \mathrm{CO}$, and $\mathrm{CH}_{4}$ products from glycerol over silica supported Ni catalyst. Under reaction conditions investigated in this study, $\mathrm{Ni} / \mathrm{SiO}_{2}$ catalyst $3 \times 5 \mathrm{~mm}$ size was found to be the best performing catalyst in terms of hydrogen production from glycerol.

\section{Materials and Methods}

2.1. Catalysts and Chemicals. Commercial Engelhard Ni$5256 \mathrm{E} \mathrm{3/64"} \mathrm{catalyst} \mathrm{containing} \mathrm{highly} \mathrm{dispersed} \mathrm{Ni} \mathrm{(57 \% )}$ on a silica support with surface area $260 \mathrm{~m}^{2} / \mathrm{g}$ was obtained. The catalyst samples were ground, and the particles with diameter as denoted in Table 1 were used in the fixed bed reactor at $2 \mathrm{~g}$ catalyst scale of operation. Glycerol laboratory grade from Qualigens Fine Chemicals India, Ltd. was used.

2.2. Characterization. The X-ray diffraction (XRD) patterns of the $\mathrm{Ni} / \mathrm{SiO}_{2}$ fresh and used catalysts were recorded with Siemens D-5000 X-ray diffractometer using Ni-filtered $\mathrm{Cu}$ $\mathrm{K} \alpha$ radiation $(\lambda=0.15406 \mathrm{~nm})$ and $2 \theta$ range between $2-80^{\circ}$. The BET surface areas of fresh and used samples were measured by $\mathrm{N}_{2}$ physical adsorption at $-196^{\circ} \mathrm{C}$ in an Autosorb-I (Quantachrome) instrument. The scanning electron microscopy (SEM) analysis of the catalysts was performed on Hitachi S-520 SEM unit. Elemental analysis was carried out using Link ISIS-300 Oxford energydispersive analysis of X-ray spectroscopy detector (EDAX). TEM studies were conducted on TECHNAI 20B2 S-Twin unit operated at $120 \mathrm{kV}$ with a filament current of $28 \mathrm{~mA}$. $\mathrm{X}$-ray photoelectron spectroscopies (XPSs) were recorded on a KRATOS AXIC 165 photoelectron spectroscopy using the $\mathrm{Mg} \mathrm{K} \alpha$ radiation. The carbon contents were measured using VARIO EL, CHNS elementary analysis that was carried out on spent catalysts.

2.3. Catalyst Evaluation. Glycerol steam reforming reactions were carried out using a fixed bed, tubular down flow quartz type reactor of $18 \mathrm{~mm}$ dia with a thermocouple of $2 \mathrm{~mm}$ width. The reactor was provided with a preheater, a syringe 


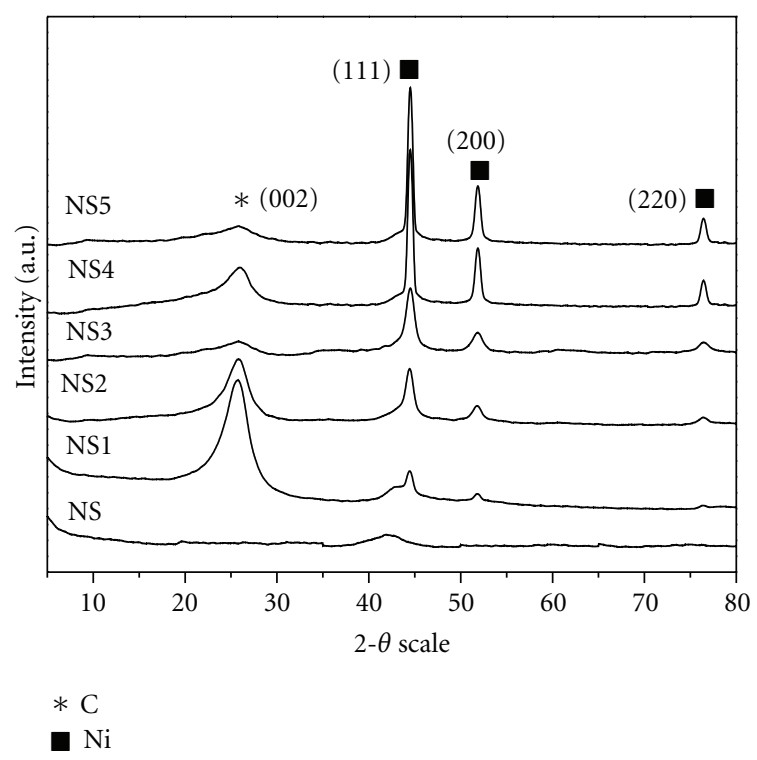

FIGURE 1: X-ray diffraction (XRD) patterns of used catalysts NS1, NS2, NS3, NS4, and NS5 and fresh NS catalyst.

pump, a cold condenser, and gas flow meter. The catalyst $(2 \mathrm{~g})$ was loaded which is supported by quartz wool at bottom of the catalyst in middle of the reactor. The reactor is placed in a tubular furnace with inner dia of $25 \mathrm{~mm}$. The feed mixture (1:9 to $1: 18$ mole ratio of glycerol to water) was fed into the vaporizer using a syringe (B. Braun) pump. The feed entering the pre-heater was maintained at $500^{\circ} \mathrm{C}$ before reaching the catalyst bed. A Nippon (NC2538) temperature controller was used for maintaining the temperature of preheating zone and catalyst bed of the reactor. The conversion of glycerol was calculated from the volume of the condensate, and the gas composition was determined by gas chromatography (SHIMADZU GC-2014) with TCD (thermal conductivity detector) using Carboxen 1000 column and Helium as carrier gas. $6 \mathrm{~mL}$ of feed was used to get $2 \mathrm{~L} \mathrm{H}_{2} \mathrm{~g}^{-1} \mathrm{cath}^{-1}$. Prior to the reaction, catalysts were reduced using $10 \% \mathrm{H}_{2} / \mathrm{N}_{2}$ in the temperature range of $450-500^{\circ} \mathrm{C} / 4 \mathrm{~h}$ with a heating rate at $10^{\circ} \mathrm{C} /$ minute. The evaluation studies were carried out for $20 \mathrm{~h}$ to $100 \mathrm{~h}$ depending on the activity level.

\section{Results and Discussion}

\subsection{Catalyst Characterization}

3.1.1. XRD. X-ray diffraction (XRD) patterns of fresh and used catalysts are shown in Figure 1. The diffraction pattern of fresh catalyst (NS) shows the characteristic peaks of $\mathrm{Ni}$ at $2 \theta=44.49^{\circ}(111)$, whereas in used catalysts, additional characteristic Ni peaks at $2 \theta=51.84^{\circ}(200)$ and $76.38^{\circ}(220)$ are observed along with the peak at $2 \theta=44.49^{\circ}$ (JCPDS no. 04-0850) [23]. The sharp characteristic peaks of $\mathrm{Ni}$ in the XRD of used samples assign the formation of crystals with defined planes during the reaction. No interactions were observed between nickel and silica. The average crystallite size calculated from Scherrer equation for fresh catalyst is $5 \mathrm{~nm}$, and in used samples, the size varied from 6 to $20 \mathrm{~nm}$ depending on the reaction conditions (Table 1). Peaks around $2 \theta=26.28^{\circ}$ (JCPDS no. 75-1621) attributed to graphitic carbon corresponding to the 002 plane of carbon in the used catalyst. Initially $2 \times 2 \mathrm{~mm}$ size catalyst was used, where the XRD graph clearly indicates high intensity of carbon than $\mathrm{Ni}$ peak due to the carbon deposition on the surface. Further $3 \times 5 \mathrm{~mm}$ size catalysts show a decrease in the peak intensity at $2 \theta=26.28^{\circ}$, simultaneously increasing intensity of $\mathrm{Ni}$ peaks. This indicates minimum carbon deposition on the surface of large pellets. The XRD patterns show that these catalysts have minimum coking rate and maintain the activity due to the surface active sites ( $\mathrm{Ni}$ crystallites).

3.1.2. BET Surface Area. The surface area values of $\mathrm{Ni} / \mathrm{SiO}_{2}$ fresh and used catalysts are shown in Table 1 . The surface area of the fresh NS catalyst is high $\left(260 \mathrm{~m}^{2} / \mathrm{g}\right)$ when compared to used catalysts due to coke formation on the surface [24].

3.1.3. SEM-EDAX. Morphology of fresh and used catalysts that are investigated by scanning electron microscopy is shown in Figure 2. The fresh catalyst shows homogeneous texture, whereas heterogeneous morphology is observed in used catalysts due to the presence of carbon content. Thus, the SEM images could depict the change in the morphology of fresh and used samples. EDAX analysis of fresh and used catalysts is provided in Table 1 . In used catalyst where the carbon content is more, the Ni content on the surface was minimum indicating that the $\mathrm{Ni}$ is covered by carbon deposition.

3.1.4. CHNS Analysis. CHNS analysis was carried out to understand the amount of carbon deposition during the course of reaction, and the data is shown in Table 1. Steam reforming of glycerol using different catalyst sizes and feed compositions are found to be effecting the carbon deposition as is evident from the analysis.

3.1.5. TEM. The results of TEM analysis are shown in Figures 3 and 4. TEM images of fresh (NS) catalyst show the fine dispersion of Ni particles on $\mathrm{SiO}_{2}$ support [25]. The size of $\mathrm{Ni}$ in fresh and used catalysts is about $5-8 \mathrm{~nm}$ and 10 $20 \mathrm{~nm}$, respectively, which is consistent with the crystallite size calculated from XRD. TEM images used catalysts that depict carbon nanofibers formed during glycerol reforming reaction over NS1, NS3, NS4, and NS5, with a diameter ranging from 30 to $60 \mathrm{~nm}$ along with $\mathrm{Ni}$ particles embedded in them.

Furthermore, the overall morphological and structural information for used samples is also obtained by SAED analysis. Figures 5(a) and 5(b) show SAED analysis of accelerated ageing with different GWMRs. The results show small difference in their morphologies. The SAED patterns of both $1: 9$ and $1: 18$ GWMRs feed for corresponding used catalysts (NS4 and NS5) show spotty ring patterns (Figures $5(\mathrm{a})$ and $5(\mathrm{~b}))$ which are indexed as cubic Ni $[26,27]$. 


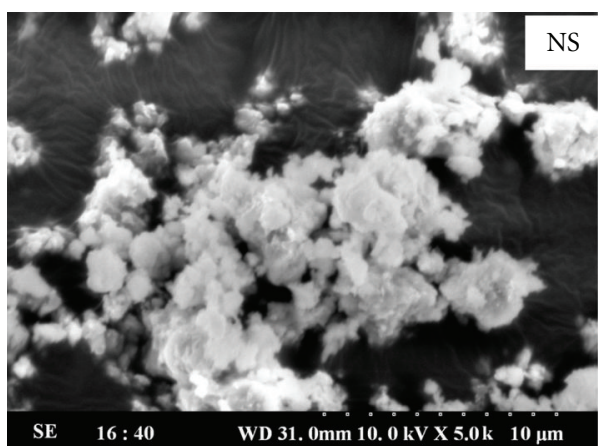

(a)

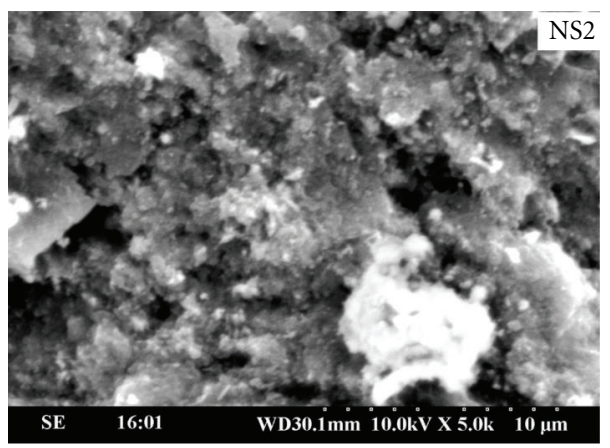

(c)

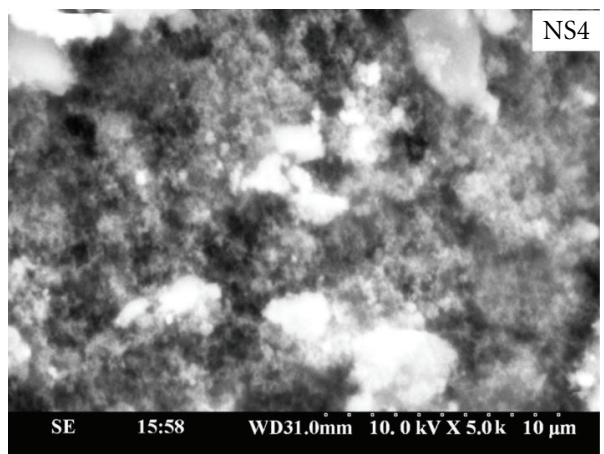

(e)

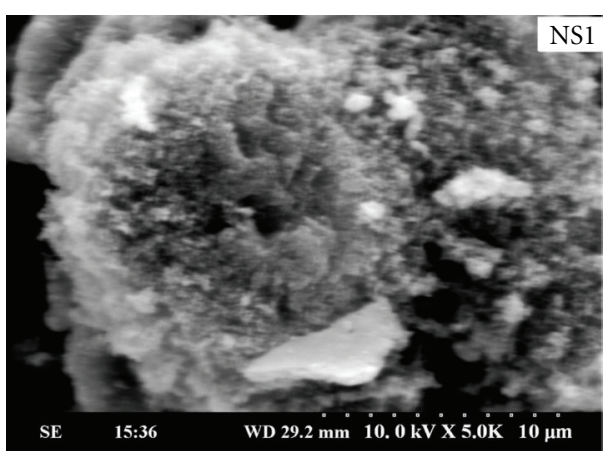

(b)

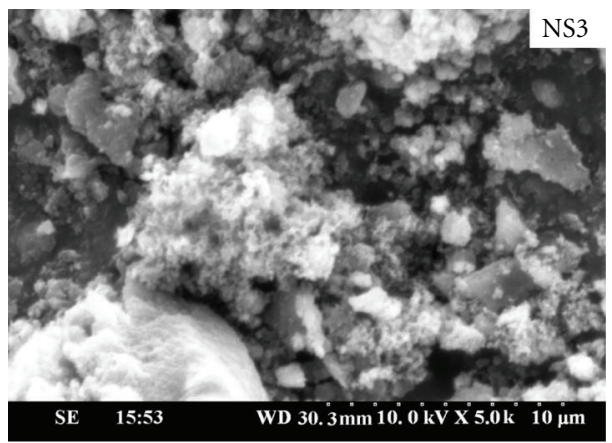

(d)

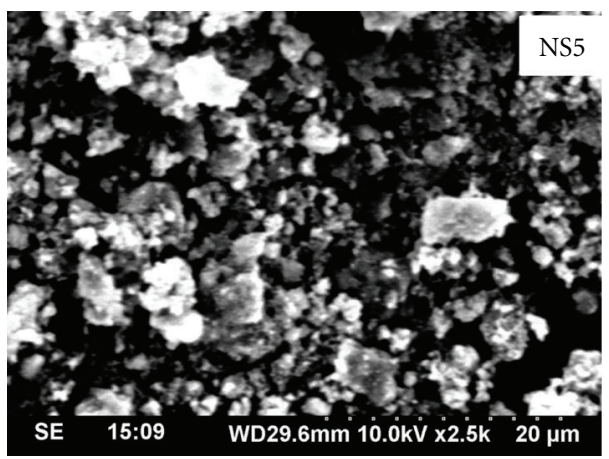

(f)

FIGURE 2: SEM images of $\mathrm{Ni} / \mathrm{SiO}_{2}$ fresh (NS) and used (NS1, NS2, NS3, NS4, and NS5) catalysts.
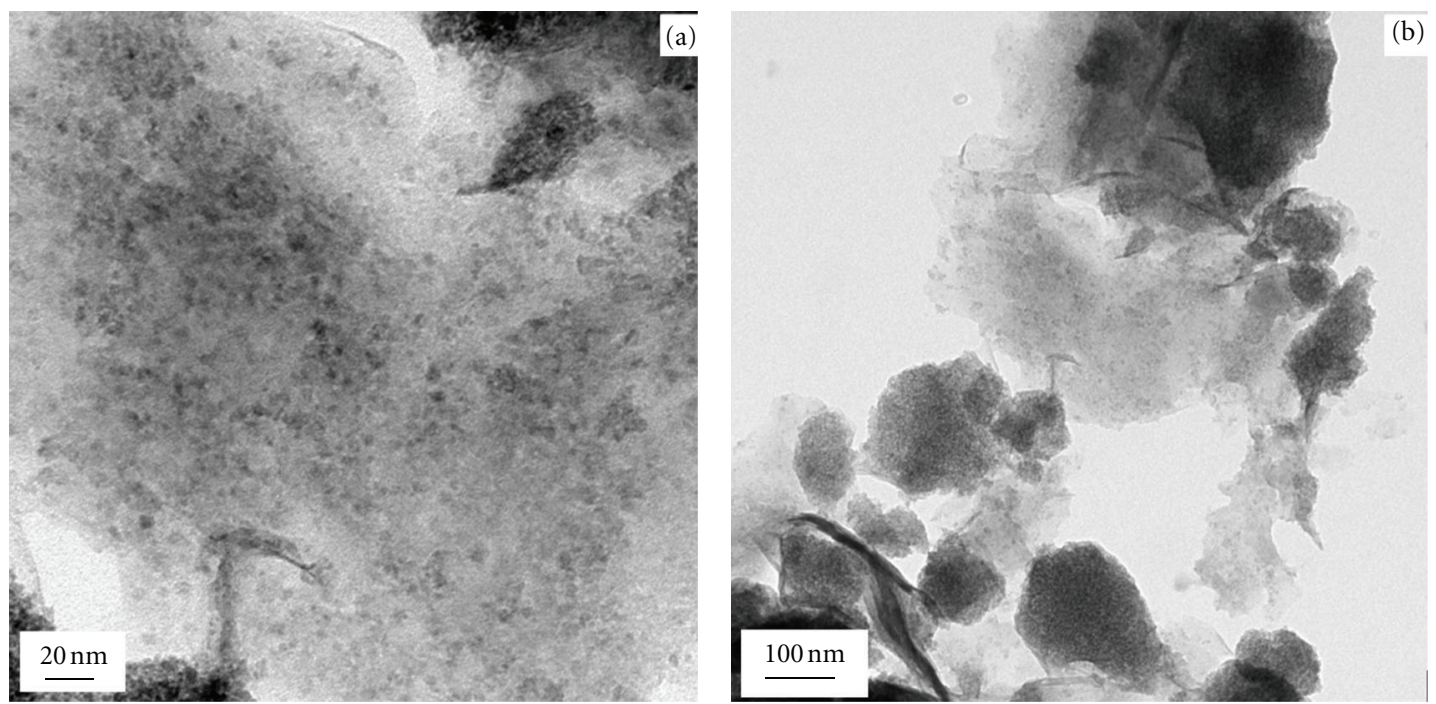

FIGURE 3: TEM images of the NS catalyst (a) $20 \mathrm{~nm}$ (b) $100 \mathrm{~nm}$. 

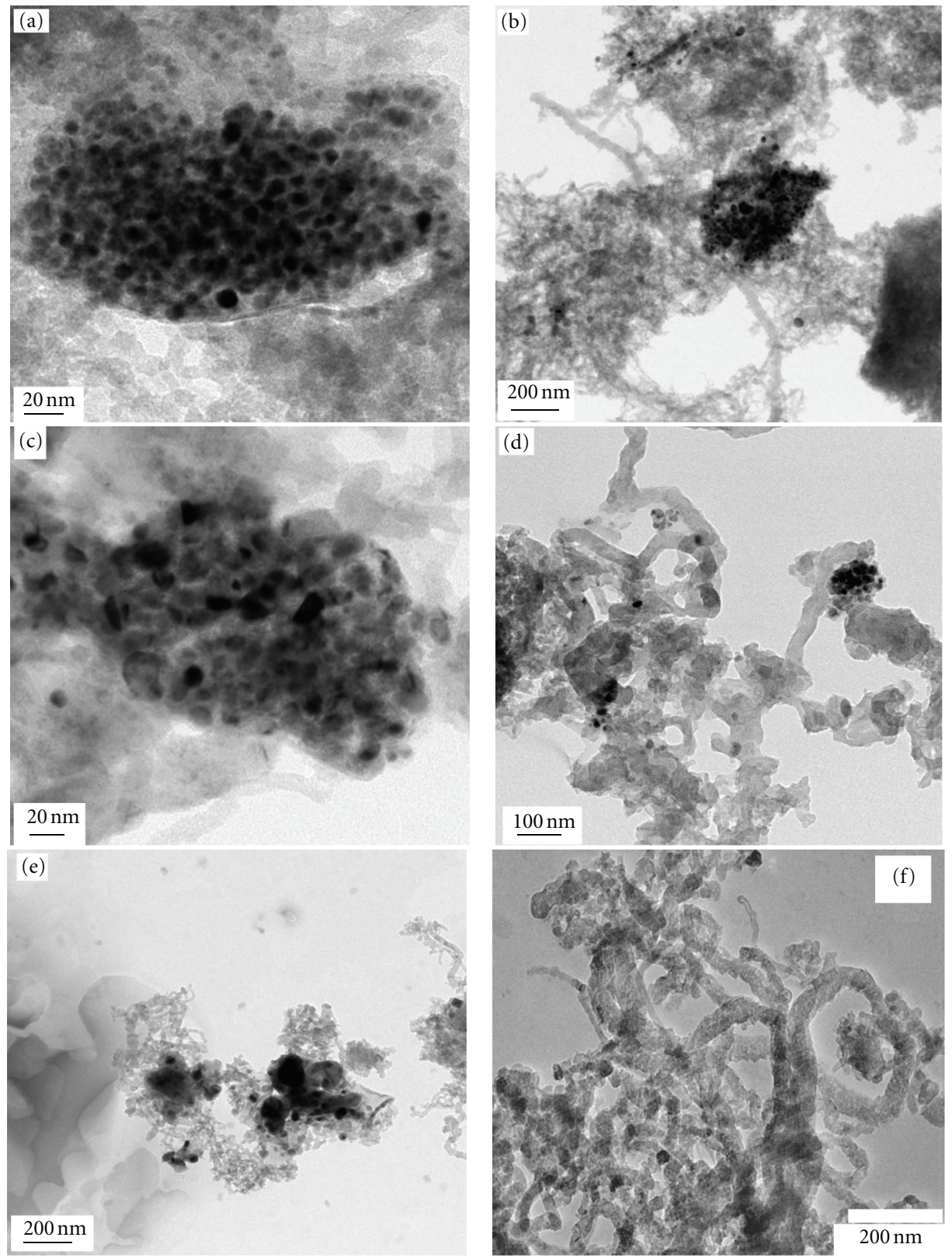

Figure 4: TEM images of Ni/SiO 2 used catalysts (a) and (b) of NS1, (c) and (d) of NS3, (e) of NS4, and (f) of NS5.

The same results are further confirmed by the XRD results (JCPDS no. 04-0850). Apart from the above, there is a slight difference between the two SAED patterns (Figures 5(a) and 5(b)) which should not be ignored. The (111), (200), (220) and (311) reflections of Ni planes in Figure 5(b) appear to be more intense than those in Figure 5(a), signifying the better crystallinity of the catalyst in accelerating ageing study with 1:18 (GWMRs). The reflection of graphite plane (002) is also observed in Figures 5(a) and 5(b) having different intensities as studied at different GWMRs conditions.

3.1.6. XPS. XPS spectra of Ni $2 \mathrm{p}_{3 / 2}$ in fresh catalyst (Figure 6(a)) show a characteristic peak at $853.7 \mathrm{eV}$ attributed to $\mathrm{Ni}^{0}$ and a satellite peak near $859.7 \mathrm{eV}$, whereas $2 \mathrm{p}_{1 / 2}$ shows
$\mathrm{Ni}^{0}$ peak at $870.6 \mathrm{eV}$ with a satellite peak around $876.9 \mathrm{eV}$ respectively [28]. Besides, Ni $2 p$ spectra show a decrease in binding energy values in the used catalyst. The Si $2 p$ spectra (Figure 6(b)) show a characteristic peak with high intensity at $103.4 \mathrm{eV}$ assigned to $\mathrm{SiO}_{2}$ (fresh), while peak at $102.6 \mathrm{eV}$ in used catalyst corresponds to silicate [29]. The O1s binding energy observed at $532.6 \mathrm{eV}$ ascribed to prominent $\mathrm{SiO}_{2}$ linkages. The decrease of $532.6 \mathrm{eV}$ peak in the intensity in the used sample spectra may be due to carbon deposition (Figure 6(c)). A peak with the highest intensity is observed in C1s spectra at $284.6 \mathrm{eV}$ corresponding to the coke deposition on the surface (Figure 6(d)). The results are in well agreement with the XRD analysis. Table 2 shows the binding energy values of $\mathrm{Ni} 2 \mathrm{p}, \mathrm{Si} 2 \mathrm{p}, \mathrm{O} 1 \mathrm{~s}$, and $\mathrm{C} 1 \mathrm{~s}$ in NS and NS1 catalysts. 


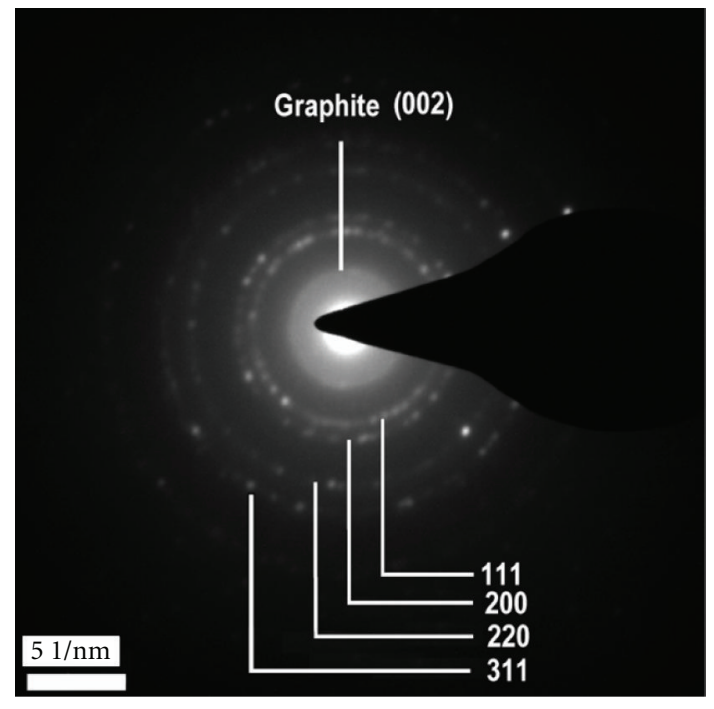

(a)

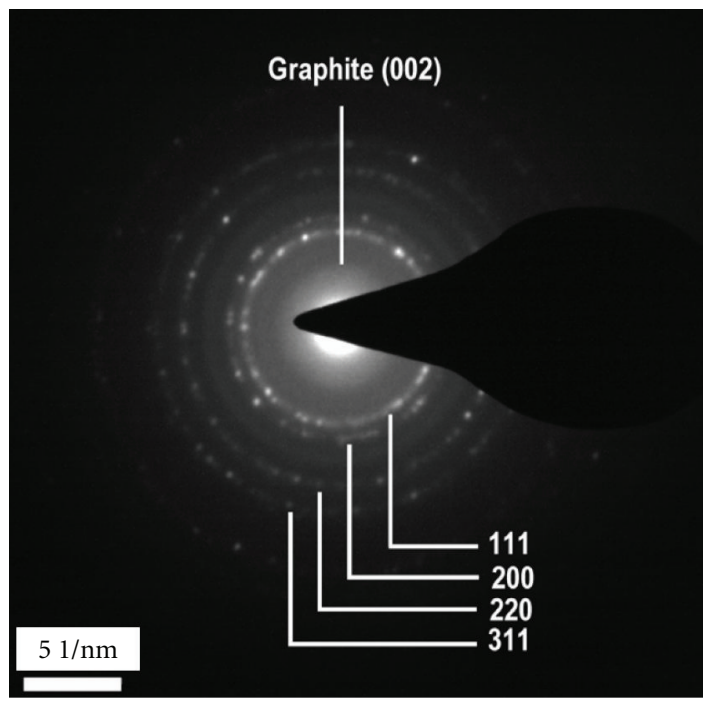

(b)

Figure 5: Selected area electron diffraction patterns from the planes $\mathrm{Ni}(111),(200),(220)$, and (311) and graphite (002) of $\mathrm{Ni} / \mathrm{SiO}_{2}$ catalysts from accelerated aging studies (a) NS4 and (b) NS5.

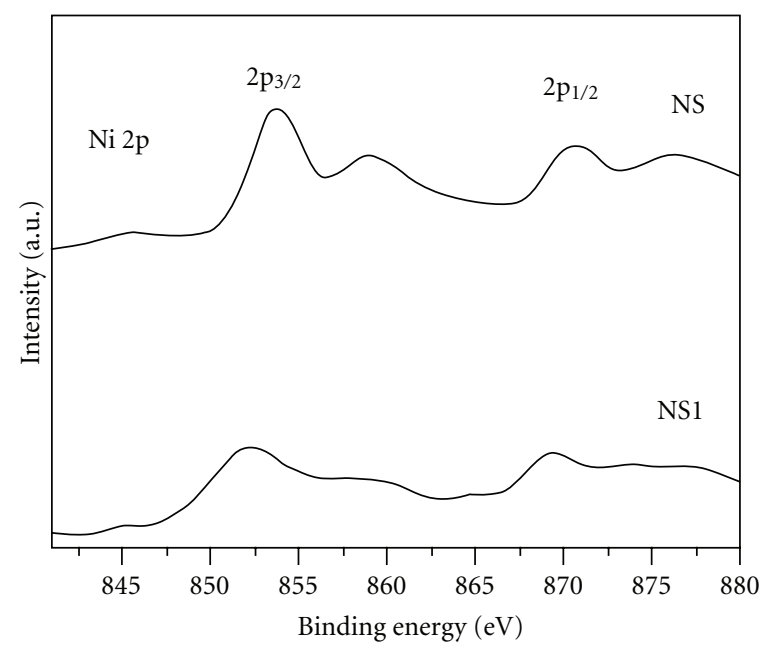

(a)

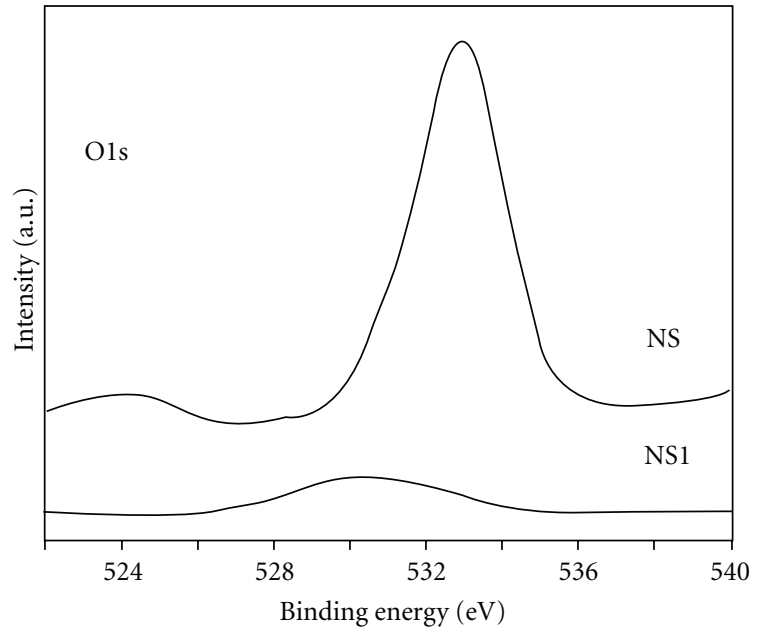

(c)

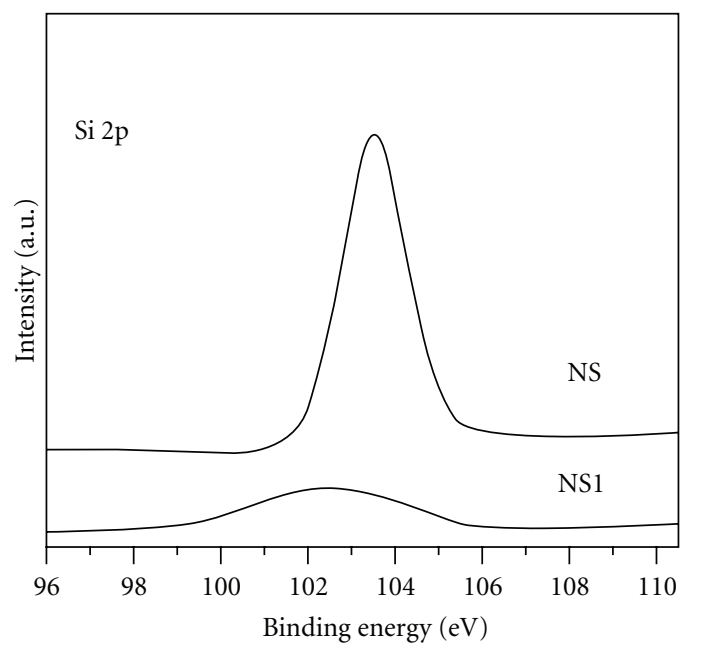

(b)

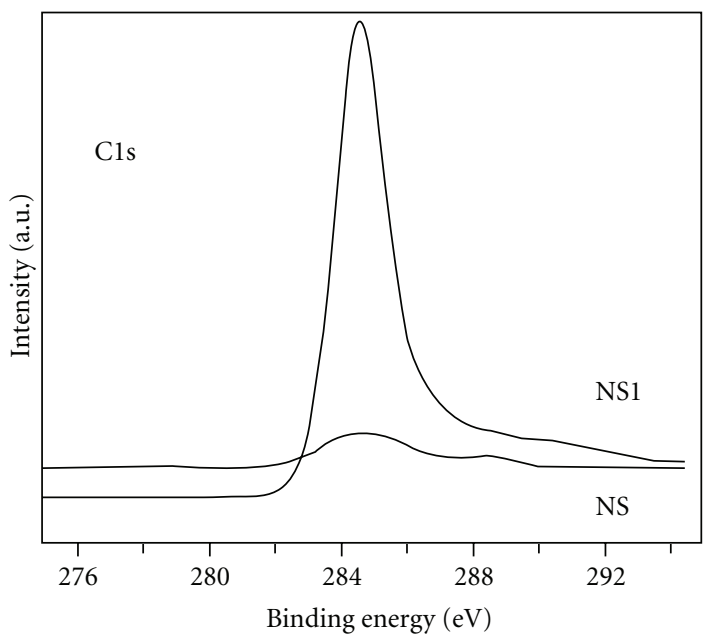

(d)

FIGURE 6: XPS Spectra of NS and NS1 catalysts (a) Ni 2p, (b) Si 2p, (c) O 1s, and (d) C1s. 


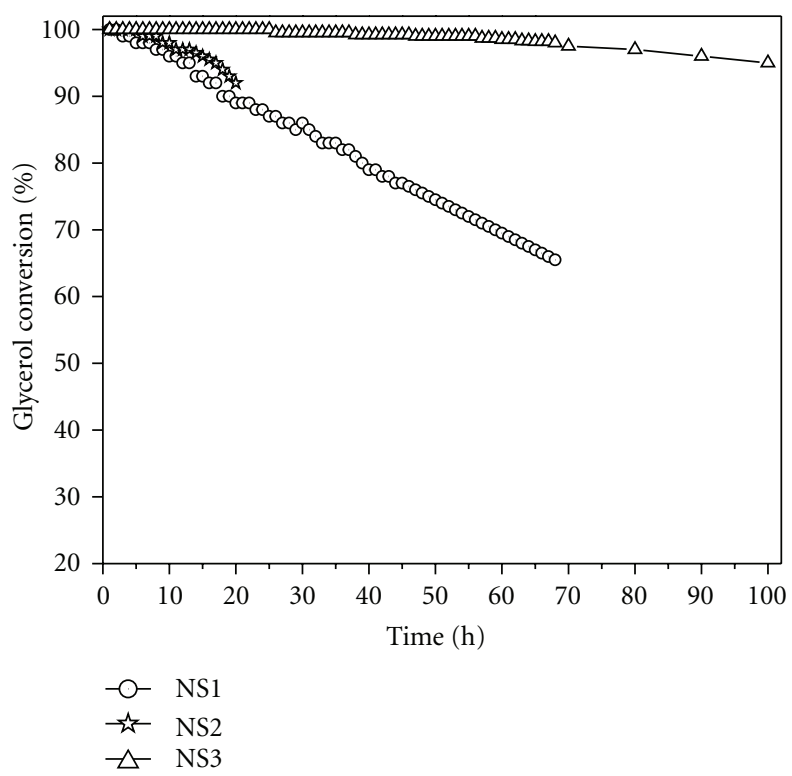

FIGURE 7: Effect of $\mathrm{Ni} / \mathrm{SiO}_{2}$ catalyst size on glycerol conversion with time on stream temp $=600^{\circ} \mathrm{C} ; \mathrm{GWMRs}=1: 9$.

TABLE 2: XPS binding energies of $\mathrm{Ni} / \mathrm{SiO}_{2}$ catalysts.

\begin{tabular}{lccccc}
\hline \multirow{2}{*}{ Catalyst $\mathrm{Ni} / \mathrm{SiO}_{2}$} & \multicolumn{5}{c}{ Binding energy (eV) } \\
& $\mathrm{Ni} 2 \mathrm{p}_{3 / 2}$ & $\mathrm{Ni} 2 \mathrm{p}_{1 / 2}$ & $\mathrm{Si} 2 \mathrm{p}$ & $\mathrm{O} 1 \mathrm{~s}$ & $\mathrm{C} \mathrm{1s}$ \\
\hline $\mathrm{NS}$ & 853.7 & 870.6 & 103.4 & 532.8 & 284.6 \\
$\mathrm{NS} 1$ & 852.3 & 869.2 & 102.6 & 530.4 & 284.6 \\
\hline
\end{tabular}

\subsection{Catalyst Performance Testing}

3.2.1. Effect of Pellet Size. Glycerol steam reforming activity studies are conducted over $\mathrm{Ni} / \mathrm{SiO}_{2}$ catalyst of different sizes at $600^{\circ} \mathrm{C}$ as shown in Figure 7. The initial reactant conversion on $2 \times 2,2 \times 4$, and $3 \times 5(\mathrm{~mm})$ pellets is $100 \%$. However, with time on stream, stable activity is observed on $3 \times 5 \mathrm{~mm}$ size pellet. The activity is seen decreasing with time, on the other two sizes, which are smaller in size, and maximum deactivation is observed on the smallest pellet $(2 \times 2 \mathrm{~mm})$. This could possibly be seen as due to the constrain in flow of the reactants due to the increased pressure on the surface that could be resolved with increasing size of the pellet. This may also be seen as due to the heavy coking on the greater surface exposed to reaction in the smaller size [30]. The catalyst particle size is critical since it alters the surface-to-volume $(\mathrm{S} / \mathrm{V})$ ratio of the catalyst. If carbon blocking of active sites is responsible for catalyst deactivation on decreasing the $\mathrm{S} / \mathrm{V}$ ratio, then an enhancement of the deactivation process should be expected. The increase in the S/V ratio increases the rate of carbon gasification enhancing the catalyst stability. Thus, further studies are made on $3 \times 5 \mathrm{~mm}$ pellet size for obtaining better operating conditions.

3.2.2. Effect of Temperature. The effect of temperature on glycerol steam reforming and product gas distribution over $\mathrm{Ni} / \mathrm{SiO}_{2} 3 \times 5 \mathrm{~mm}$ catalyst with $1: 9$ mole ratios of glycerol to water is shown in Figure 8 and Table 3. The increase
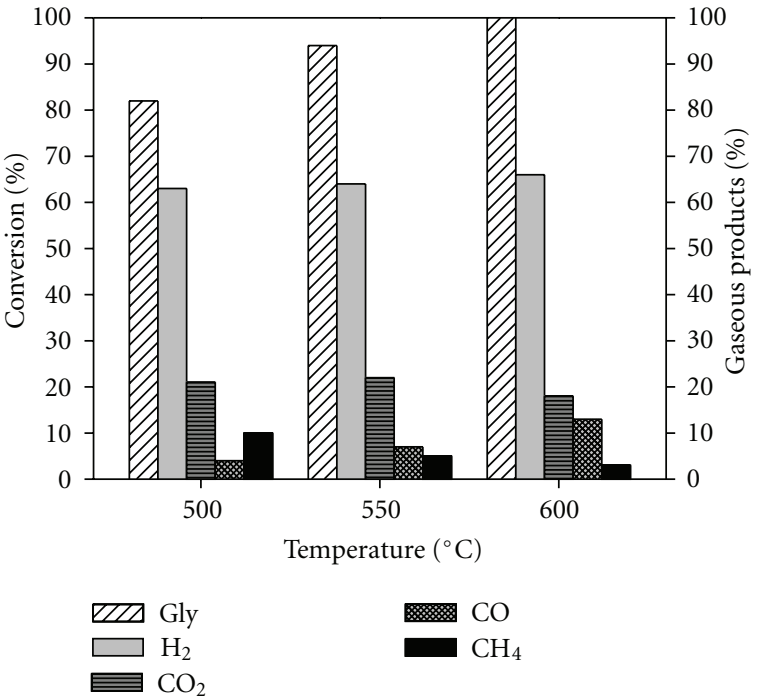

Figure 8: Effect of temperature on gas phase product distribution for the glycerol steam reforming over $\mathrm{Ni} / \mathrm{SiO}_{2}(3 \times 5 \mathrm{~mm})$; GWMRs $=1: 9$.
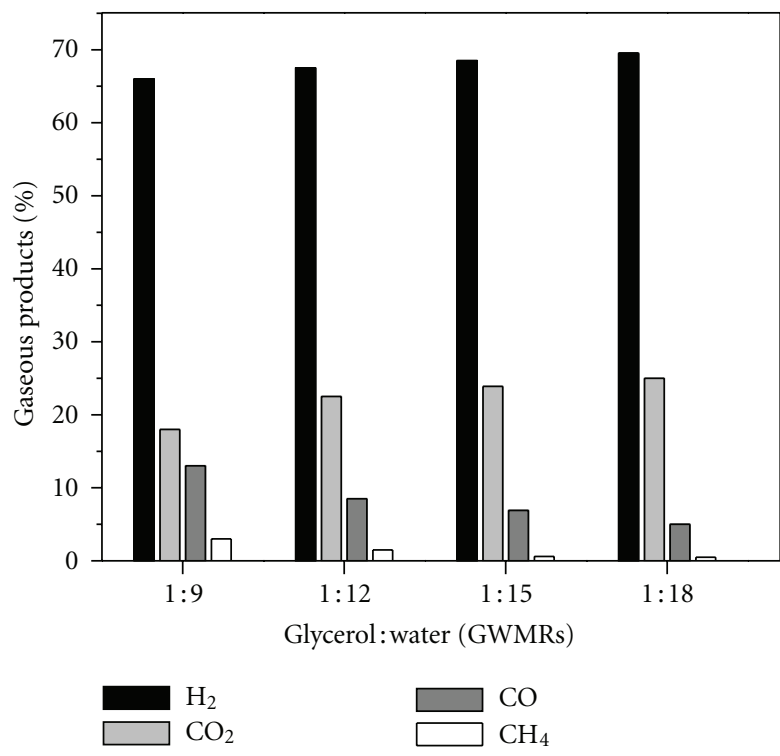

FIGURE 9: Effect of GWMRs on glycerol steam reforming over $\mathrm{Ni} / \mathrm{SiO}_{2},(3 \times 5 \mathrm{~mm})$; temp $=600^{\circ} \mathrm{C}$.

in temperatures from 500 to $600^{\circ} \mathrm{C}$, increases the glycerol conversion $(80-100 \%)$. Around $500^{\circ} \mathrm{C}$, the product gas distribution shows more of $\mathrm{CH}_{4}$ and $\mathrm{CO}_{2}$ conforming methanation and water gas shift reaction. At $600^{\circ} \mathrm{C}$ increase in $\mathrm{CO}$ formation and decrease in $\mathrm{CO}_{2}$ show that the reverse water gas shift reaction is predominant in (5) and (2) [3134]. A nominal increment is observed in $\mathrm{H}_{2} \%$ at $600^{\circ} \mathrm{C}$ temperature:

$$
\mathrm{CO}+3 \mathrm{H}_{2} \longrightarrow \mathrm{CH}_{4}+\mathrm{H}_{2} \mathrm{O}
$$

3.2.3. Effect of GWMRs (Glycerol-to-Water Mole Ratio). Figure 9 and Table 3 explain the gas distribution at $600^{\circ} \mathrm{C}$ 
TABLE 3: Glycerol conversion and product gas distribution in the glycerol steam reforming over $\mathrm{Ni} / \mathrm{SiO}_{2}(3 \times 5 \mathrm{~mm})$.

\begin{tabular}{|c|c|c|c|c|c|c|c|}
\hline \multirow{2}{*}{ S. no. } & \multirow{2}{*}{ Temp $\left({ }^{\circ} \mathrm{C}\right)$} & \multirow{2}{*}{ GWMRs } & \multirow{2}{*}{ Glycerol conversion (\%) } & \multicolumn{4}{|c|}{ Product gas distribution (vol \%) } \\
\hline & & & & $\mathrm{H}_{2}$ & $\mathrm{CO}_{2}$ & $\mathrm{CO}$ & $\mathrm{CH}_{4}$ \\
\hline 1 & 500 & $1: 9$ & 82 & 63 & 21.5 & 4.5 & 11 \\
\hline 2 & 550 & $1: 9$ & 94 & 63.5 & 22.5 & 7.5 & 6.5 \\
\hline 3 & 600 & $1: 9$ & 100 & 66 & 18 & 12.5 & 3.5 \\
\hline 4 & 600 & $1: 12$ & 100 & 67.5 & 22.5 & 8.5 & 1.5 \\
\hline 5 & 600 & $1: 15$ & 100 & 68.5 & 23.9 & 6.9 & 0.6 \\
\hline 6 & 600 & $1: 18$ & 100 & 69.5 & 25 & 5 & 0.5 \\
\hline
\end{tabular}

temperature with different GWMRs. Decrease in GWMRs ( $1: 9$ to $1: 18$ mole ratio) shows an increase in $\mathrm{H}_{2}$ and $\mathrm{CO}_{2}$, and simultaneously and a decrease of $\mathrm{CO}$ and $\mathrm{CH}_{4}$ that may be seen due to more favored methane steam reforming and reverse water gas shift reaction under the conditions of study [6] as follows:

$$
\begin{aligned}
& \mathrm{CH}_{4}+2 \mathrm{H}_{2} \mathrm{O} \longrightarrow \mathrm{CO}_{2}+4 \mathrm{H}_{2} \\
& \mathrm{CO}_{2}+\mathrm{H}_{2} \stackrel{\text { Rev-WGS }}{\longrightarrow} \mathrm{CO}+\mathrm{H}_{2} \mathrm{O}
\end{aligned}
$$

3.2.4. Accelerated Ageing Studies. Catalyst life is evaluated by accelerated ageing studies, and the importance of this study is to reduce time of evaluation and manpower wastage and to evaluate catalyst life time in a short period. Accelerating ageing studies over the $\mathrm{Ni} / \mathrm{SiO}_{2}$ catalyst $(3 \times 5 \mathrm{~mm})$ are conducted by changing the operational temperatures in a cycling manner between 600 and $700^{\circ} \mathrm{C}$ temperature, and the feed rate is doubled. The effect of GWMRs on catalytic conversion and coke deposition is studied under similar conditions. Figure 10(a) shows the glycerol conversion as a function of accelerated ageing for 20 experimental cycles (each cycle is $600^{\circ} \mathrm{C} / 1 \mathrm{~h}$ and $700^{\circ} \mathrm{C} / 1 \mathrm{~h}$; feed rate is doubled) at 1:9 GWMRs. After 20 cycles of reaction operation, $20 \%$ fall is observed for glycerol conversion, and $3 \mathrm{mg}$ carbon $\mathrm{g}^{-1} \mathrm{cath}^{-1}$ has deposited on the catalyst. In order to minimize the coke deposition, accelerating ageing studies are conducted with 1:18 GWMRs in similar conditions and the results are shown in Figure 10(b). Only $10 \%$ fall is observed in glycerol conversion after 20 cycles, and

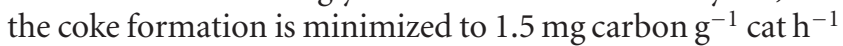
(Table 1) [35].

3.3. Coke Formation. Carbon deposition occurs mainly by the decomposition of $\mathrm{CO}, \mathrm{CH}_{4}$, and thermal cracking of hydrocarbons depending on the conditions like temperature and partial pressures of reactants and products. Different morphologies of coke may form, namely, pyrolytic carbon, encapsulating carbon, whisker, and carbides. However, the nature and morphology depend on the active metal, metal particle size, and hydrocarbon source. Besides, at high temperatures polyaromatic or even graphitic compounds are formed. Carbon depositions on the surface of the catalyst will result in several undesirable reactions, and products affecting the purity of reformation and carbon also cause loss of effective surface area. As discussed earlier, the coke formation
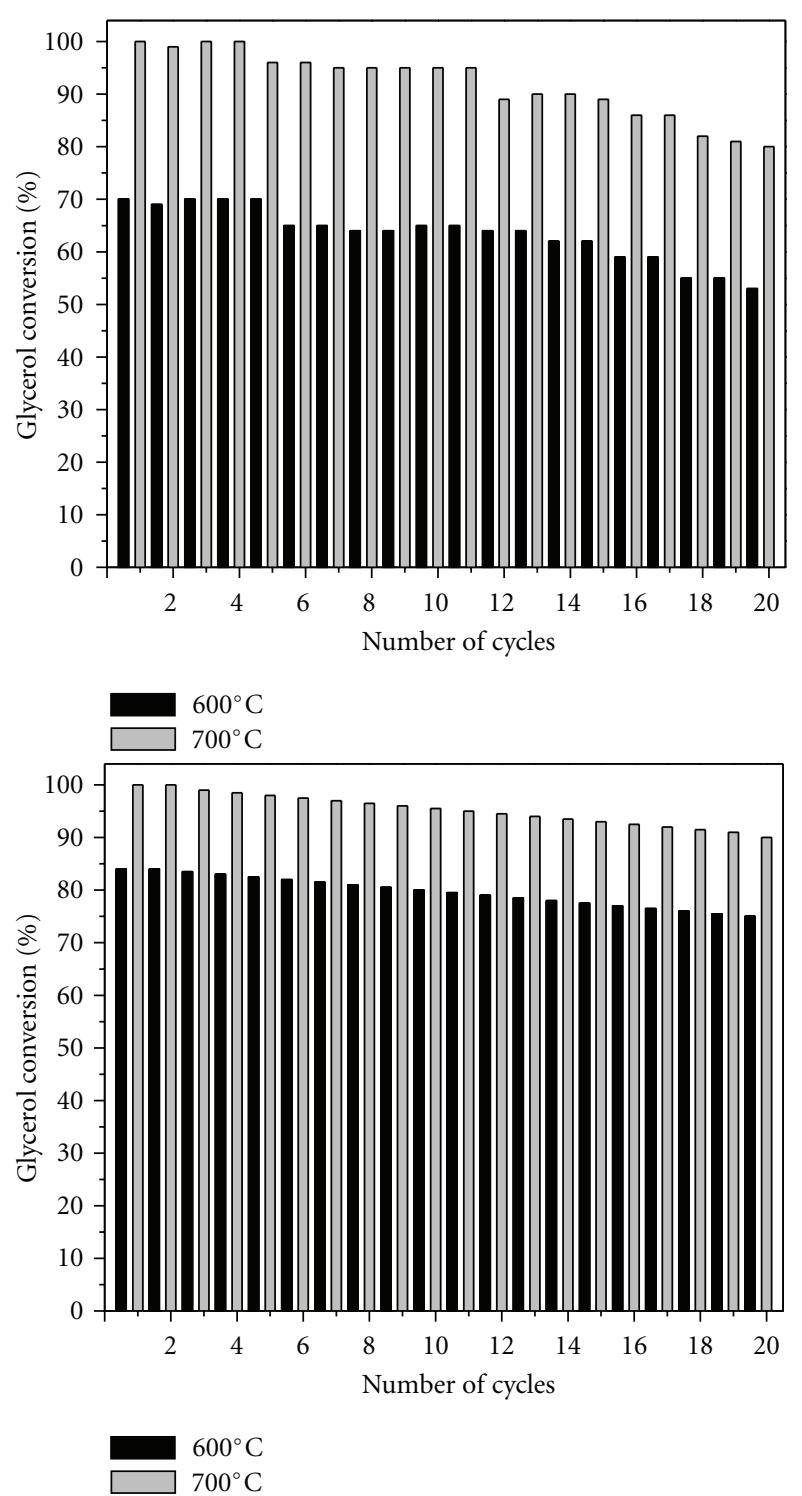

Figure 10: Accelerated ageing studies of $\mathrm{Ni} / \mathrm{SiO}_{2}(3 \times 5 \mathrm{~mm})$ with GWMRs (a) 1:9 and (b) 1:18 for glycerol steam reforming.

is not desirable in the steam reforming process. Compared to higher pellet size $(3 \times 5 \mathrm{~mm})$ of the catalyst lower pellet size catalysts $(2 \times 2,2 \times 4 \mathrm{~mm})$ exhibit a greater tendency to form carbon at $600^{\circ} \mathrm{C}$ with $1: 9$ GWMRs. Furthermore, 


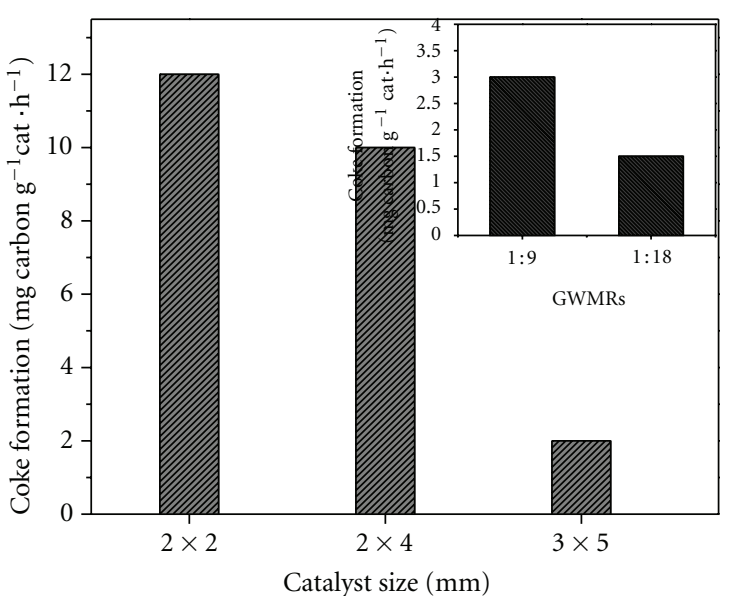

Figure 11: Effect of the particle size on the comparison of coke formation; temp $=600^{\circ} \mathrm{C}$; GWMRs: $1: 9$. Inset: effect of the GWMRs on the coke formation on $3 \times 5 \mathrm{~mm}$ particle size catalyst.

higher particle size $(3 \times 5 \mathrm{~mm})$ is investigated subjecting to accelerating aging studies using different GWMRs to minimize coke formation. Figure 11 clearly explains carbon formation rate in steam reforming of glycerol; 10 $12 \mathrm{mg}$ carbon $\mathrm{g}^{-1} \mathrm{cath}^{-1}$ is observed on $\mathrm{Ni} / \mathrm{SiO}_{2}(2 \times 2 ; 2 \times$ $4 \mathrm{~mm}$ ) catalysts. With increased pellet size $3 \times 5 \mathrm{~mm}$, the carbon formation observed is only $2 \mathrm{mg}$ carbon $\mathrm{g}^{-1} \mathrm{cat} \mathrm{h}^{-1}$. In accelerated aging studies with 1:9 GWMRs, carbon formation rate is $3 \mathrm{mg}$ carbon $\mathrm{g}^{-1} \mathrm{cath}^{-1}$, and with further decreasing GWMRs to $1: 18$, the formation rate has decreased to $1.5 \mathrm{mg}$ carbon $\mathrm{g}^{-1} \mathrm{cath}^{-1}$. These observations evidence that minimization of the coking formation rate is by increasing the catalyst pellet size and decreasing GWMRs. The coke formation is estimated by CHNS analysis that is provided in Table 1.

\section{Conclusions}

The present study illustrates the effects of catalyst pellet size in $\mathrm{H}_{2}$ production through glycerol steam reforming, where the small pellets promote the coke formation at high temperature $\left(600^{\circ} \mathrm{C}\right)$. The higher pellet size improves the catalytic performance as well as minimizes coke formation. A minimum amount of $1.5 \mathrm{mg}$ carbon $\mathrm{g}^{-1} \mathrm{cath}^{-1}$ coke was observed under accelerating ageing studies for (GWMRs $1: 18$ ). The detailed characterization of the fresh and used catalyst allows a better understanding of catalysts behavior under glycerol steam reforming conditions. The results illustrate that carbon formation is mainly responsible for the deactivation of the catalyst, and the sustainability can be achieved by optimizing favorable reaction conditions.

\section{Acknowledgments}

G. Sadanandam thank CSIR, New Delhi, for SRF Grant and also the authors thank MNRE, New Delhi, for funding this project.

\section{References}

[1] BIODIESEL 2020, A Global Market Survey, Feedstock Trends and Forecasts, Emerging Markets Online, 2nd edition, 2008.

[2] J. N. Chheda, G. W. Huber, and J. A. Dumesic, "Liquidphase catalytic processing of biomass-derived oxygenated hydrocarbons to fuels and chemicals," Angewandte ChemieInternational Edition, vol. 46, no. 38, pp. 7164-7183, 2007.

[3] M. Balaraju, V. Rekha, P. S. Sai Prasad, R. B. N. Prasad, and N. Lingaiah, "Selective hydrogenolysis of glycerol to 1, 2 propanediol over $\mathrm{Cu}-\mathrm{ZnO}$ catalysts," Catalysis Letters, vol. 126, no. 1-2, pp. 119-124, 2008.

[4] C. H. Zhou, J. N. Beltramini, Y. X. Fan, and G. Q. Lu, "Chemoselective catalytic conversion of glycerol as a biorenewable source to valuable commodity chemicals," Chemical Society Reviews, vol. 37, no. 3, pp. 527-549, 2008.

[5] A. J. Byrd, K. K. Pant, and R. B. Gupta, "Hydrogen production from glycerol by reforming in supercritical water over $\mathrm{Ru} / \mathrm{Al}_{2} \mathrm{O}_{3}$ catalyst," Fuel, vol. 87, no. 13-14, pp. 2956-2960, 2008.

[6] S. Adhikari, S. Fernando, and A. Haryanto, "A comparative thermodynamic and experimental analysis on hydrogen production by steam reforming of glycerin," Energy and Fuels, vol. 21, no. 4, pp. 2306-2310, 2007.

[7] K. Lehnert and P. Claus, "Influence of Pt particle size and support type on the aqueous-phase reforming of glycerol," Catalysis Communications, vol. 9, no. 15, pp. 2543-2546, 2008.

[8] S. M. Swami and M. A. Abraham, "Integrated catalytic process for conversion of biomass to hydrogen," Energy and Fuels, vol. 20, no. 6, pp. 2616-2622, 2006.

[9] N. Luo, X. Fu, F. Cao, T. Xiao, and P. P. Edwards, "Glycerol aqueous phase reforming for hydrogen generation over $\mathrm{Pt}$ catalyst-effect of catalyst composition and reaction conditions," Fuel, vol. 87, no. 17-18, pp. 3483-3489, 2008.

[10] F. Pompeo, G. F. Santori, and N. N. Nichio, "Hydrogen production by glycerol steam reforming with $\mathrm{Pt} / \mathrm{SiO}_{2}$ and $\mathrm{Ni} / \mathrm{SiO}_{2}$ catalysts," Catalysis Today, vol. 172, pp. 183-188, 2011.

[11] G. Wen, Y. Xu, H. Ma, Z. Xu, and Z. Tian, "Production of hydrogen by aqueous-phase reforming of glycerol," International Journal of Hydrogen Energy, vol. 33, no. 22, pp. 66576666, 2008.

[12] B. Dou, V. Dupont, P. T. Williams, H. Chen, and Y. Ding, "Thermogravimetric kinetics of crude glycerol," Bioresource Technology, vol. 100, no. 9, pp. 2613-2620, 2009.

[13] J. W. Shabaker, G. W. Huber, and J. A. Dumesic, "Aqueousphase reforming of oxygenated hydrocarbons over Snmodified Ni catalysts," Journal of Catalysis, vol. 222, no. 1, pp. 180-191, 2004.

[14] S. Czernik, R. French, C. Feik, and E. Chornet, "Hydrogen by catalytic steam reforming of liquid byproducts from biomass thermoconversion processes," Industrial and Engineering Chemistry Research, vol. 41, no. 17, pp. 4209-4215, 2002.

[15] S. Adhikari, S. Fernando, and A. Haryanto, "Production of hydrogen by steam reforming of glycerin over aluminasupported metal catalysts," Catalysis Today, vol. 129, no. 3-4, pp. 355-364, 2007.

[16] P. D. Vaidya and A. E. Rodrigues, "Glycerol reforming for hydrogen production: a review," Chemical Engineering and Technology, vol. 32, no. 10, pp. 1463-1469, 2009.

[17] V. Nichele, M. Signoretto, F. Menegazzo et al., "Glycerol steam reforming for hydrogen production: design of Ni supported catalysts," Applied Catalysis B, vol. 111-112, pp. 225-232, 2012. 
[18] B. Zhang, X. Tang, Y. Li, Y. Xu, and W. Shen, "Hydrogen production from steam reforming of ethanol and glycerol over ceria-supported metal catalysts," International Journal of Hydrogen Energy, vol. 32, no. 13, pp. 2367-2373, 2007.

[19] R. R. Soares, D. A. Simonetti, and J. A. Dumesic, "Glycerol as a source for fuels and chemicals by low-temperature catalytic processing," Angewandte Chemie-International Edition, vol. 45, no. 24, pp. 3982-3985, 2006.

[20] V. Chiodo, S. Freni, A. Galvagno, N. Mondello, and F. Frusteri, "Catalytic features of $\mathrm{Rh}$ and $\mathrm{Ni}$ supported catalysts in the steam reforming of glycerol to produce hydrogen," Applied Catalysis A, vol. 381, no. 1-2, pp. 1-7, 2010.

[21] S. Adhikari, S. D. Fernando, S. D. F. To, R. M. Bricka, P. H. Steele, and A. Haryanto, "Conversion of glycerol to hydrogen via a steam reforming process over nickel catalysts," Energy and Fuels, vol. 22, no. 2, pp. 1220-1226, 2008.

[22] S. Adhikari, S. Fernando, S. R. Gwaltney et al., "A thermodynamic analysis of hydrogen production by steam reforming of glycerol," International Journal of Hydrogen Energy, vol. 32, no. 14, pp. 2875-2880, 2007.

[23] J. Ashok, S. Naveen Kumar, A. Venugopal, V. Durga Kumari, and M. Subrahmanyam, "COX-free $\mathrm{H}_{2}$ production via catalytic decomposition of $\mathrm{CH}_{4}$ over $\mathrm{Ni}$ supported on zeolite catalysts," Journal of Power Sources, vol. 164, no. 2, pp. 809 814, 2007.

[24] C. K. Cheng, S. Y. Foo, and A. A. Adesina, "Carbon deposition on bimetallic Co-Ni/ $\mathrm{Al}_{2} \mathrm{O}_{3}$ catalyst during steam reforming of glycerol," Catalysis Today, vol. 164, no. 1, pp. 268-274, 2011.

[25] S. Tomiyama, R. Takahashi, S. Sato, T. Sodesawa, and S. Yoshida, "Preparation of $\mathrm{Ni} / \mathrm{SiO}_{2}$ catalyst with high thermal stability for $\mathrm{CO}_{2}$-reforming of $\mathrm{CH}_{4}$," Applied Catalysis A, vol. 241, no. 1-2, pp. 349-361, 2003.

[26] T. Yamauchi, Y. Tsukahara, K. Yamada, T. Sakata, and Y. Wada, "Nucleation and growth of magnetic Ni-Co (CoreShell) nanoparticles in a one-pot reaction under microwave irradiation," Chemistry of Materials, vol. 23, no. 1, pp. 75-84, 2011.

[27] M. Sanles-Sobrido, M. Bañobre-López, V. Salgueiriño et al., "Tailoring the magnetic properties of nickel nanoshells through controlled chemical growth," Journal of Materials Chemistry, vol. 20, no. 35, pp. 7360-7365, 2010.

[28] T. Sakamoto, K. Asazawa, K. Yamada, and H. Tanaka, "Study of Pt-free anode catalysts for anion exchange membrane fuel cells," Catalysis Today, vol. 164, no. 1, pp. 181-185, 2011.

[29] C. D. Wagner, W. M. Riggs, L. E. Davis, J. F. Moulder, and G. E. Muilenberg, Eds., Handbook of X-Ray Photoelectron Spectroscopy, PerkineElmer Corporation, 1979.

[30] L. F. Bobadilla, A. álvarez, M. I. Domínguez et al., "Influence of the shape of Ni catalysts in the glycerol steam reforming," Applied Catalysis B, vol. 123-124, pp. 379-390, 2012.

[31] M. L. Dieuzeide and N. Amadeo, "Thermodynamic analysis of Glycerol steam reforming," Chemical Engineering and Technology, vol. 33, no. 1, pp. 89-96, 2010.

[32] I. N. Buffoni, F. Pompeo, G. F. Santori, and N. N. Nichio, "Nickel catalysts applied in steam reforming of glycerol for hydrogen production," Catalysis Communications, vol. 10, no. 13, pp. 1656-1660, 2009.

[33] M. Slinn, K. Kendall, C. Mallon, and J. Andrews, "Steam reforming of biodiesel by-product to make renewable hydrogen," Bioresource Technology, vol. 99, no. 13, pp. 5851-5858, 2008.

[34] B. Dou, V. Dupont, G. Rickett et al., "Hydrogen production by sorption-enhanced steam reforming of glycerol," Bioresource Technology, vol. 100, no. 14, pp. 3540-3547, 2009.
[35] V. Durga Kumari, K. Venkateswarlu, M. Subrahmanyam et al., " $\mathrm{H}_{2}$ production activities at Indian Institute of Chemical Technology," in International Conference on Hydrogen Production, The Korean $\mathrm{H}_{2}$ and New Energy Society, Seoul, Korea, June 2012. 

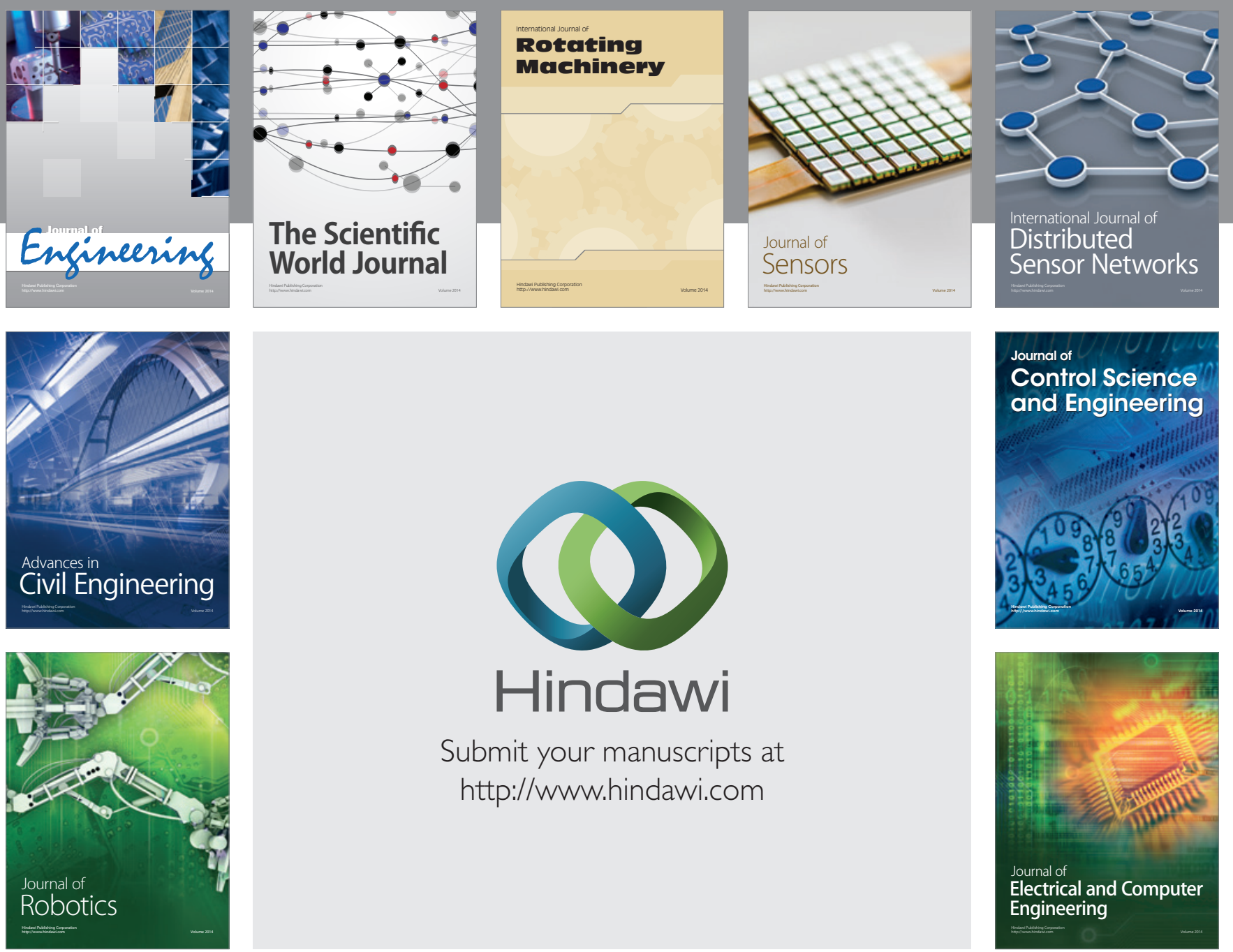

Submit your manuscripts at

http://www.hindawi.com
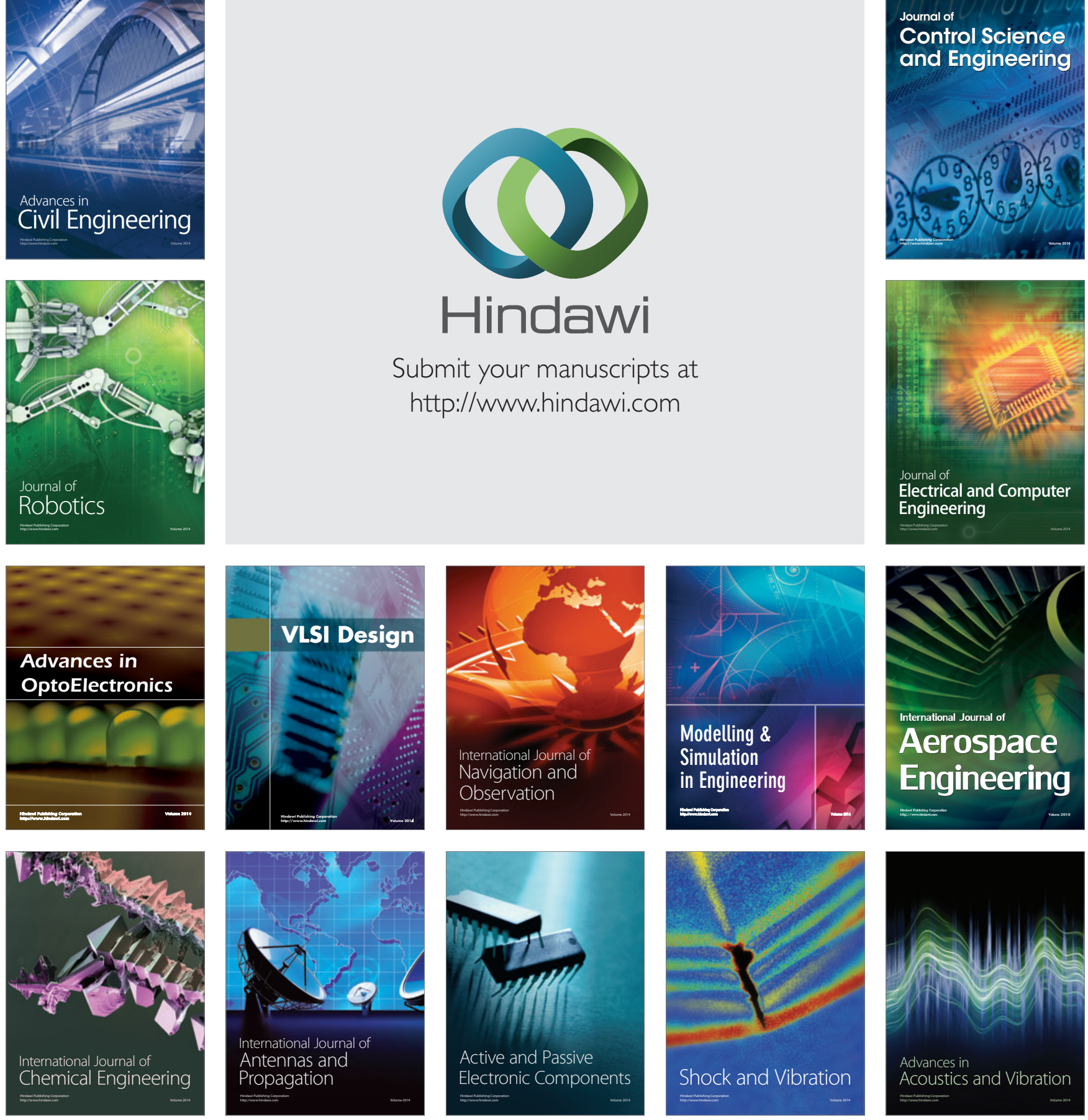